Covered in: Web of Sciences (WOS); EBSCO; ERIH+; Google Scholar; Index Copernicus; Ideas RePeC; Econpapers; Socionet; CEEOL; Ulrich ProQuest; Cabell, Journalseek; Scipio; Philpapers; SHERPA/RoMEO repositories; KVK; WorldCat; CrossRef; CrossCheck

\section{Students' Views on the Covid-19 \\ pandemic: Attitudes, Representations, and Coping Mechanisms}

\section{Gabriela Monica ASSANTE1, Octav Sorin CANDEL2}

${ }^{1}$ Assistant Professor, PhD, Alexandru Ioan Cuza University, Iaşi, Romania, panzaru.monica@yahoo.com

2 Assistant Professor, PhD, Alexandru Ioan Cuza University, Iaşi, Romania, octav.candel@,uaic.ro
Abstract: The new developments in our social context, the recent pandemic outbreak, caused a series of changes in everyday practices. The student population represents a particular case, both their safety and future education were under duress during this period. However, their views over the situation have not been present in the scientific literature. The present qualitative research aimed to explore students' perceptions, attitudes, views, and representations on the Covid-19 pandemic. Three focus groups, each containing twelve participants, were organised to explore these aspects and students' particular experiences. Focus group sessions were audio-recorded and the transcripts were analysed. The results revealed four dimensions of the students' representations: change - as a constant of the present, prospective scenarios, the pulse of the moment, and surrounding risks. The limitations and the importance of the study are discussed. The consequences of these representations are particularly important due to the influence they can have on people's practices during the crisis and the extent of measures' acceptance. The results offer precious insights on why some communication strategies used by the authorities had a low compliance rate, what should be done differently, and what should be considered in order to promote adaptive health behaviors during the latter phases of the pandemic.

Keywords: COVID-19 pandemic; representations; fear; distrust; conspiracy.

How to cite: Assante, G. M., \& Candel, O. S. (2020). Students' Views on the Covid-19 pandemic: Attitudes, Representations, and Coping Mechanisms. Postmodern Openings, 11(4), 347-365. doi:10.18662/po/11.4/240 


\section{Introduction}

The Coronavirus disease 19 (Covid-19) has entered Europe and spread across multiple countries during the first half of 2020. In Romania, the first case was confirmed on 28 February 2020, and even earlier in the month, the first preventive measures were taken by the government. Starting March 16th, the country entered in an emergency state, all the activities in the universities were suspended and the teaching activities moved towards an online environment. However, the preceding period, characterized by important social changes, brought significant anxiety and confusion among the population (Brooks at al., 2020). Based on these changes and taking into account that people's opinion during the early phase of a pandemic could be an indicator of how they would respond to the protective measures, we aimed to examine the attitudes towards the new type of coronavirus, the changes related to it, the emotions and the attitudes towards the prospective scenarios experienced by a student population.

Starting from 21 February 2020, the Romanian Government imposed a series of protection measures against the Covid-19. People coming from other states (such as Italy or Spain) had to be quarantined for 14 days upon entering the country, both indoor and outdoor activities were suspended or took place with a reduced number of participants and, as a more controversial measure, the Orthodox Church suggested that the Eucharist rite should be performed with one's own spoon. The media started to extensively present news about the pandemic and many shops and markets reported incidents of panic buying. These early measures, although they were not as extreme as some changes imposed during the emergency state and lockdown period, brought a higher level of awareness and a rise in various opinions, views, and attitudes towards the virus and the pandemic. The student population was particularly interested in the situation. On 9 March all the primary and secondary education was suspended but a decision about higher education was pending. Thus, many students were confused and felt threatened by the situation. In this context, the student population became particularly noteworthy. They faced the same issues as all the other Romanian citizens, but they were also in a situation that was specific only to them. To our knowledge, there is no other study that took into account the European students' perceptions, attitudes, and views on the Covid-19 pandemic. In China, university students reported having mostly negative psychological symptoms. However, strong mediatization led to high perception of risk and compliance with hygiene practices (Yang et al., 2020). Thus, examining the Romanian student population during the early days of 
the pandemic might provide valuable information. Firstly, understanding how students view the situation might provide sufficient data to develop intervention tools and methods to help them overcome the problems specific to the latter stages of the pandemic. Secondly, their early attitudes and behavior about the pandemic can act as important clues regarding the people's subsequent behavior during the crisis. Finally, this research on a Romanian population can be integrated with a continental or global trend interested in people's opinions on the pandemic.

This research is framed within several theoretical frameworks. Firstly, the Social Representation Theory (Moscovici, 1988) proposes that each topic is characterized by "a system of information, beliefs, opinions, and attitudes" (Paez \& Perez, 2020, p. 1). Social representations are specific to different groups and they influence public awareness and understanding. Two processes are used to build the content of the representations: anchoring (comparing the new topic with an older, familiar one; ie. comparing Covid-19 with the flu or with HIV) and objectification (transforming an idea into a tangible object; ie. vilify the government or presenting the doctors as heroes) (Paez \& Perez, 2020). Social Representations Theory has the main benefit of theorizing lay knowledge including the cultural, historical, and social structures of the context under consideration. In this sense, lay knowledge is community knowledge, produced by people, in conditions of social interaction and communication, expressing their identities, interests, history, and culture. Moreover, being concerned with meaning and interpretation, it is central for social representations to understand how people express identity, develop patterns of behavior, and engage with significant others (Wagner et al., 1999).

Because they have high rates of propagation and dissemination, social representations are a viable resource when studying people's attitudes towards different diseases and were recommended as a tool to understand and predict opinions and behaviors during the Covid-19 pandemic (Jaspal \& Nerlich, 2020; Paez \& Perez, 2020). Moreover, this framework was used when studying Spanish children's representations of the pandemic (Idoiaga et al., 2020).

Secondly, we drew from the Social Identity Theory (Tajfel \& Turner, 1979) and the Referent Informational Influence Theory (Abrams \& Hogg, 1990). Individuals have the knowledge that they belong to a social group and thus develop various attitudes based on the norms of the social group or those of the most prototypical members of the group (Smith \& Hogg, 2008). These attitudes determine both their collective behavior and how they view other groups (Hogg et al., 2017). Given that the Covid-19 pandemic was 
associated with a significant rise in stigmatization and prejudice (Roberto et al., 2020), it would be interesting to examine whether these attitudes towards the out-group would also be specific for the student population.

Finally, from a postmodern view, the Covid-19 pandemic allowed people to develop various narratives to explain what is happening to them (Gilder, 2020; Mamzer, 2020). Not only this, but the pandemic allows the researcher to study the individual more clearly. Thus, one can focus on the very different stories (narratives) created by the students, on how they interfere with each other on how they reflect the opinion of different social structures and systems of beliefs.

Thus, this study aimed to develop a better understanding of the students' attitudes towards the Covid-19, the social changes it brought, and the prospective scenarios they foresee. It recent months, various studies investigated the knowledge and views of different populations regarding the topic, such as Indian, Malaysian and German adults (Azlan et al., 2020; Roy et al., 2020: Zipprich et al., 2020) Chinese students (Yang et al., 2020) or Spanish children (Idoiaga et al., 2020). However, this would be the first study to concentrate on European Students (to our knowledge) and one of the few studies to use a qualitative method to explore this topic. The research has an exploratory nature; thus we did not propose hypotheses. However, we tried to offer answers to three different research questions. coronavirus?

1. What were the students' attitudes towards the new type of

2. What changes related to the pandemic would the students present?

3. What emotions did the students experience?

\section{Methodology}

For the research purpose, to explore participants' subjective views and experiences regarding the changes related to the new type of coronavirus, focus groups were considered the most advantageous method for data gathering. Primarily because focus groups contribute to the development of various communication lines, stimulate thinking and communication between the participants and create a safe place where participants can share personal experiences, ideas, and beliefs regarding a certain phenomenon. Therefore, the participant and its perception of the world is situated at the center of this method (Payne \& Payne, 2004). The significant interactions between the participants, in contrast with the reduced interaction with the moderator of the group, results in a more leading role 
given to participants' opinion (Madriz, 2000). Also, the reduced interaction with the moderator is considered as an effective way to elicit responses that better reflect the social realities of the interviewees (Kruger, 1994).

To be on firmer ground when making claims about the patterning of the data, we choose to organize three different focus-groups. Based on this, it can be concluded that the differences observed are not just a characteristic of one singular group but are likely to be related to the various characteristics of participants reflected in selection (Barbour, 2008). The focus groups took place on three consecutive days, starting with March 10th 2020, in the same week when Universities announced their closure.

The interview guide used in the focus-groups consists of six openquestions focused around three thematic areas: students' views about the novel coronavirus, present and future developments, attitudes and practices in the pandemic context, and the emotions triggered by all the changes occurred in the social field. Therefore, the focus groups addressed the following issues: the attitudes towards the new type of coronavirus, the changes related to it, the emotions experienced, and the attitudes towards the prospective scenarios.

\subsection{Participants}

For this study, three focus groups were organized, having twelve participants each, summing thirty-six participants. The participants were students enrolled in the second and third year in an Educational Sciences Bachelor Programme. All the participants volunteered to take part in the research. All the volunteers were female. The sessions were audio-recorded after receiving the consent and the audio content transcribed.

\subsection{Data analysis}

The transcripts were analyzed through an inductive process of categories development from the texts. It aimed at establishing the emerging thematic areas from the participants' discourse related to the views towards the new type of coronavirus. From the transcripts, the relevant blocks of the text related to the research purpose were selected. The relevant segments of text received a code, as similar as possible to the original statement. These codes were the basis for category development. In the coding process, the codes and the categories were regularly revised for obtaining an exhaustive analysis (Huberman \& Miles, 1994). Two researchers analyzed and coded the transcripts at the same time. The resulted coding systems were then compared and the distribution of text to certain categories was discussed. The resulted inter-rater reliability index held a value of 0.89 . Following this 
process, the final coding system was developed. This was used to organize the data in patterns which then served as a basis for analysis and interpretation (Silverman, 2000).

\section{Results}

The analysis of the focus group discussions resulted in four major themes related to the attitudes towards the new type of coronavirus: change - as a constant of the present, prospective scenarios, the pulse of the moment, and surrounding dangers [Table 1].

Table 1. Results of the thematic analysis of the focus groups

\begin{tabular}{|c|c|c|c|}
\hline Themes & Categories & Sub-categories & Frequency \\
\hline \multirow{8}{*}{$\begin{array}{l}\text { I. Change - as } \\
\text { a constant of } \\
\text { the present }\end{array}$} & \multirow{4}{*}{$\begin{array}{l}\text { By } \\
\text { governmental } \\
\text { authorities }\end{array}$} & $\begin{array}{l}\text { 1. Incoherent and low } \\
\text { unity measures }\end{array}$ & 20 \\
\hline & & $\begin{array}{l}\text { 2. Lack of responsibility } \\
\text { for the message sent - } \\
\text { manipulation of } \\
\text { information and lack of } \\
\text { trust }\end{array}$ & 19 \\
\hline & & $\begin{array}{l}\text { 3. } \begin{array}{l}\text { Discriminatory } \\
\text { measures }\end{array}\end{array}$ & 10 \\
\hline & & $\begin{array}{l}\text { 4. Lack of preventive } \\
\text { measures }\end{array}$ & 6 \\
\hline & \multirow[t]{3}{*}{$\begin{array}{l}\text { By religious } \\
\text { authorities }\end{array}$} & $\begin{array}{l}\text { 1. Disagreement with the } \\
\text { measures entailed by } \\
\text { the religious } \\
\text { institutions }\end{array}$ & 18 \\
\hline & & $\begin{array}{l}\text { 2. The church as a safe } \\
\text { place }\end{array}$ & 11 \\
\hline & & $\begin{array}{l}\text { 3. Agreement with the } \\
\text { measures entailed by } \\
\text { the religious } \\
\text { institutions }\end{array}$ & 16 \\
\hline & $\begin{array}{l}\text { Intrapersonal } \\
\text { changes }\end{array}$ & $\begin{array}{l}\text { 1. Negative emotions } \\
\text { experienced }\end{array}$ & 29 \\
\hline
\end{tabular}


Students' Views on the Covid-19 pandemic: Attitudes, Representations ... Gabriela Monica ASSANTE, Octav Sorin CANDEL

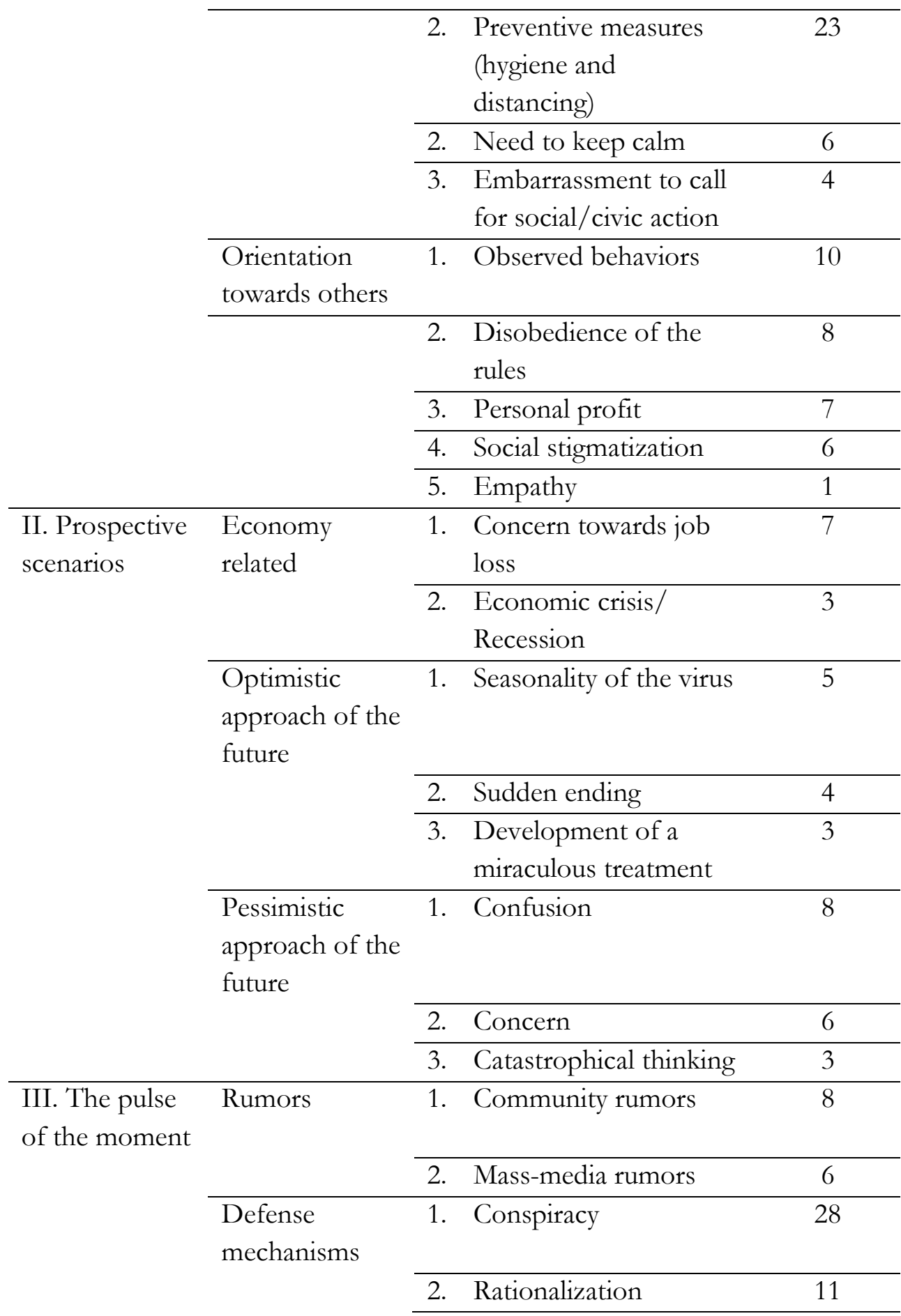




\begin{tabular}{|c|c|c|c|}
\hline & & 3. Fatalism & 10 \\
\hline & & 4. Humor and sarcasm & 1 \\
\hline IV. & Physical & 1. Public transportation & 7 \\
\hline Surrounding & environment & & \\
\hline & & 2. Crowded areas & 4 \\
\hline & Social & 1. Lack of trusted & 8 \\
\hline & environment & information channels & \\
\hline & & $\begin{array}{l}\text { 2. Rural vs. urban } \\
\text { mentality }\end{array}$ & 8 \\
\hline & & 3. Panic & 5 \\
\hline & & 4. Individualism & 4 \\
\hline
\end{tabular}

Source: Authors' own conception

\subsection{Change - as a constant of the present}

The first theme, change as a constant of the present, shows that the main impact of the new type of coronavirus reflected on the changes engaged at different levels: governmental, religious institutions, intrapersonal, and interpersonal. The social and personal changes were mainly related to the measures implemented to prevent the spread of the new type of virus.

The main set of measures was implemented by governmental authorities. The participants accused the lack of preventive measures from their part, the lack of coherent and unitary measures, the discriminatory measures, and the lack of responsibility for the message. The last category was reflected by the alleged concealment of information. For most participants, the delay in closing the schools, the universities, and even the borders were considered thoughtless. They accused a lack of proper preventive measures by stating: This is the Romanian way, that if nothing happens, there is no action, and if it happens. Other participants supported this claim by saying: We should get pass this though ... to close the schools ... are they waiting for a case? They should at least close to sanitize it. Are they waiting for something bad to happen to act?. The participants further expressed that they see many measures as discriminatory, inconsistent, and non-unified. The main concern was related to the fact that schools and kindergartens were being closed but the Universities remained open. For example, one student said: we feel discriminated because other institutions, like kindergartens, are closed, no measure was taken in 
our school. Furthermore, the participants emphasized the idea that if kindergartens and schools are closing, the parents should also work from home, because this measure should apply to all. Additionally, the participants manifested an increased lack of trust in the medical and governmental authorities as well as in the measures implemented by them.

Moreover, the participants signalled the measures applied by the religious institutions. Even if some of them agreed with the preventive measures taken there, most of them did not. They believed that preventive measures in a spiritual place are not necessary. In this sense, one's faith would have a protective nature. For example, one participant emphasized this idea by saying: The ones that have faith...I don't know, it's something above a virus that you can catch... You have to believe, if you go to church you are not going to take it, you need to have faith.

Beside the focus on the governmental authorities and religious institutions, the focus on oneself and the other members of the community, also increased. The participants stated the importance of personal hygiene, isolation, distancing, and the need for calm to overcome this unprecedented situation. Another personal change was reported - the embarrassment acting as a suppressant when the situation called for social action. For instance, many participants reported that they felt embarrassed asking others to respect the measures during this pandemic situation. To illustrate this aspect, one participant said: If someone doesn't follow the rules, I feel like telling them that they should do it, but I still don't say it because I'm ashamed. Another large topic was also approached when discussing the personal changes, namely the emotions related and triggered by this situation. Participants mentioned that they were experiencing many negative feelings such as fear, concern, confusion, and mental pressure.

When focusing on the other members of the community the participants agreed that in general, the others don't obey the implemented measures and that some people try to take personal advantage from this situation. Social stigmatization was another important issue revealed by the analysis. The participants mentioned that foreign students might represent a danger in spreading the virus, as well as the Romanian workers returning home. These social categories were considered as dangerous for spreading the virus. For this to be prevented, some measures should be taken (i.e. let no one enter the country, close the borders, they refuse quarantine, (Romanian) people who come from Italy). In contrast, only one participant expressed empathy towards this category of people by saying: "Maybe they are afraid to get sick in a foreign country". 
Negative behaviours of others were also reported. Aggressive behaviour, irascibility, exaggeration, and individualism were reported as being associated with the way people manifest in the public space. For instance, someone recounted the following incident she witnessed: In their attempt to protect themselves, people have very strange reactions. On the bus was a child with some health issues and he sneezed. Then a man started screaming at him and asking him to leave the bus, that he is acting careless, that he makes other people sick. A reaction far too out of ... the ordinary. You can't yell at a child for sneezing. To a child ... who has a problem, I mean no, he was a child.

\subsection{Prospective scenarios}

The focus group participants were well aware of the potential economic impact created by the pandemic situation, such as recession or loss of jobs. The pessimistic scenarios included confusion and concern towards the future, as well as catastrophic thinking. Regarding this approach, one student participant stated: quite a few countries and cities will be quarantined, and we will behave worse than during communism. Furthermore, one participant said that man is the devil on the earth.

There were also some optimistic prospective scenarios. Some participants believed in the development of a miraculous treatment, that the pandemic situation will suddenly end or they hoped for the seasonality of the virus.

\subsection{The pulse of the moment}

The third theme revealed by the analysis depicts the pulse of the moment, or how the participants perceive and cope with the occurrence of this new type of virus. This theme shows that many rumours spread in the community regarding the measures to be taken: there was a rumour in the Ministry of National Defence, my husband works there, that in case of quarantine, they are also in quarantine, and later a member of each family is appointed to collect certain groceries. Cases of infection were also subject to rumours: Last night $I$ heard from a friend in the dormitory: she told me that yesterday or the day before yesterday they took a girl. She had a fever, a cough, she was sick and fainted and took her to the hospital. I understood that there is another case in another dorm. The way mass-media reported on this new type of virus was mainly perceived as a way to induce panic, to spread rumours or to favour financial gain. As one participant put it: The media somehow takes advantage of this virus and they debate this topic just for the 
audience. This way of approaching the situation by spreading rumours contributed to amplify confusion and virus-related myths. Participants considered that the media had the main objective to manipulate, induce panic and anxiety. One participant emphasized that the media is playing with peoples' minds.

When society is confronted with something new, an illness, or an object, individuals are making efforts to assimilate, understand, and make sense of this new situation. In this sense, the participants indicated various defence mechanisms. Here we identified the tendency to rationalize. For the most part, it was used to refuse to acknowledge the reality or lessen the perception of an action's negative effects. For example, many participants supported the following affirmation: if $\mathbf{I}$ catch the virus today, I will transmit it to you... and if tomorrow... these things happen. Also, the participants manifested a tendency towards fatalism, as suggested by the following statement: if you're going to catch it, you're going to catch it anyway, it's not like you can do anything to prevent it. Moreover, the psychological need to understand the world predictably, to find world order leads to strong beliefs in conspiracy theories. Because, chaos is uncomfortable, as well as not finding someone responsible for the current situation, and the cause-effect proportionality bias leads participants to believe that the virus is meant to exterminate the population, especially the elderly or to destroy the economy. Many participants asserted that the virus was developed by some entities because old people live too long and that pulls the economy down", or ,to reduce the population because there are too many people in this world and they thought to destroy them.

A unique approach to the situation, in terms of singularity, was humour and sarcasm. Only one participant used humour to describe the current situation and sarcasm to describe future behaviour: We will be dressed in a radiation suit and everything will be like at Chernobyl.

\subsection{Surrounding risks}

During the focus group discussions, the participants also concentrated on emphasizing the potential surrounding risks which can contribute to a faster spread of the virus. In the physical environment, an increased degree of danger was attributed to public transportation and crowded areas. Furthermore, considering the social environment, various factors such as panic, the lack of trustworthy information sources, individualism, or the reasoning of people from rural areas were regarded as potentially destabilizing factors. 
To overcome the challenges of the present situation, participants signalled the importance of keeping calm and gathering the information from trusted sources. The individualism, which was associated also with the compulsive buying behaviour, was seen as an amplifier of this aversive situation.

A separation line was drawn between people from rural and urban areas. The participants believed that in the rural community people will be harder to convince to comply with the new preventive measures, in comparison to urban areas. It was generally believed that the ones living in urban areas will watch over the behaviour of those around them, whilst the ones in the rural area have a more positive attitude towards life and will carry on with their lives as they did before: People at the countryside are more positive, they are under the impression that nothing can make them sick, that this is not something serious.

\section{Discussion}

The process of providing an effective and sustainable set of protective measures in the COVID-19 pandemic context must be informed by individuals views, attitudes, and representations regarding the new type of coronavirus. A better knowledge of how this phenomenon is perceived will hopefully help in crisis management. This research focused on exploring students' attitudes and representations over the situation because they represent a population affected in a particular way by this crisis, in terms of both safety and educational future. We tried to find answers to three different research questions: (1) What were the students' attitudes towards the new type of coronavirus?; (2) What changes related to the pandemic would the students present?; (3) What emotions did the students experience?.The focus group analysis showed that the main results are focused around social stigma, distrust of the authorities, and conspiracy in terms of representations, as well as negative emotions experienced, lack of critical thinking, humour and empathy.

According to the current findings, social stigmatization was an issue revealed by the analysis. The participants identified various social categories, such as foreign students or expatriates returning home as dangerous regarding the spread of the virus. Therefore, it seems that potential menaces resulting from outgroup members are perceived as riskier than potential menaces resulting from individuals with whom we share a strong social identity (Cruwys et al., 2020). Here, stigma served as the cognitive basis of social grouping. A consequence of stigmatization was the unfavorable 
treatment, and discrimination suggested by the participants (Herek, 2007). The preventive measures suggested by the participants implied denying some fundamental rights.

The distrust of the authorities and conspiracy related beliefs portrayed a representation of the new coronavirus pandemic which might have reduced the effectiveness of the efforts to contain the outbreak. These representations could have some effects on discouraging people from getting treatment or from cooperating with the government. Misinformation and conspiracy beliefs regarding the new coronavirus have spread considerably, discrediting credible sources of information. Conspiracy theories, rumours, and misinformation have also spread during other epidemics such as HIV, having visible effects in some regions to this day (Mian \& Khan, 2020). Many scientists have united to fight this issue by promoting clear, open, and transparent data on this outbreak (Calisher et al., 2020).

The distrust of the authorities and the tendency towards confining conspiracy theories are particularly important results due to the influence they can have on practices and the extent of measures' acceptance. In the pandemic context, the communication strategies of the authorities must be effective and transparent, aiming at reducing information asymmetries. Confusion spread to the population will develop a group of individuals vulnerable in fighting a public health crisis (Mian \& Khan, 2020). Nonetheless, during a crisis, social media plays a major role. The communication environment they provide can be predominated with conflicting and inaccurate information that can be disseminated by individuals and groups. The recent outbreak, but also other similar crises, has emphasized the need for a thorough social media communication strategy that will enhance and support crisis response. Misinformation or rumors of a crisis event can hinder authorities' efforts as they develop a crisis communication strategy (Mirbabaie et al., 2020). Social Representations Theory explains how conspiracy beliefs enable individuals to make sense of the reality, of sudden events and ambiguous situations. Because, chaos is uncomfortable, individuals must find and explanation for the current situation to cope and lower the anxiety (Franks et al., 2013).

To produce better health outcomes, authorities, media, and the citizens must collaborate. Governments need to be transparent and effectively communicate new policies to citizens. Nevertheless, citizens need to comply with the policy and participate in the development of desired policy outcomes ( $\mathrm{Li}, 2020)$. 
Many participants experienced negative emotions caused by the pandemic (especially fear) but also by their social interactions. Some of them were ashamed to do the right thing, such as correcting erroneous behaviours related to hygiene. Negative emotions are common during medical crises and can even have benefic outcomes, such as stronger respect for social distance and hygiene (Harper et al., 2020; Ornell et al., 2020). However, they can also evolve into depression or anxiety, thus representing an important risk factor for the development of mental health issues during and following the pandemic (Ornell et al., 2002). Also, some participants expressed considerable fatalism towards the situation, believing that they cannot do much to protect themselves and their close ones. Fatalism is considered a maladaptive belief and is related to weak behavioural changes during illness and to lower quality of life (Shen et al., 2009). Moreover, fatalism can be viewed as a precursor of fear. During a pandemic, people might think that they have no power against the virus and thus, live in a perpetual state of fear and uncertainty.

Many responses confirm that future teachers tend to be in agreement, at least partially, with information related to conspiracy theories or believe in unproven communal rumors, a result that was also present in similar populations from other countries (Mikušková, 2018). This also shows that in order to develop better responses (both cognitive and emotional) during future crises, there is a great need to target critical thinking skills. Previous studies showed that using an analytical thinking style can reduce the belief in conspiracy theories (Swami et al., 2014). Moreover, better developed critical thinking would help individuals to be less judgemental towards others, reducing both social stigma and other-blame strategies (Douglas et al., 2016).

Finally, the respondents also had more beneficial attitudes regarding the crisis, but these were less frequent. Although used scarcely in our sample, humor can have a positive effect on reducing anxiety during the pandemic (Savitsky et al., 2020). However, during difficult times such as these, the usage of humor can also lower positive affects (Zacher \& Rudolph, 2020). It is important for students to remain positive and use humor in a healthy manner instead of transforming in gallows humor, which can also be a feature of fatalism. Some participants expressed empathy towards the expatriates who returned to the country or towards the children and the parents affected by the closing of schools. Empathy during the crisis is a benefic strategy because it makes people adhere to health-promoting behaviors (wearing masks and self-distancing) (Pfattheicher et al., 2020). 
This research shows that students had used different narratives about the Covid-19 pandemic even from the beginning of this period in Romania. Some of them asserted their support for the measures imposed by the state, while others doubted the measures. Also, they expressed different levels of support for various social changes, such as the closing of the Church or the return of the expatriates. They adhered to various social representation, even though many of them were maladaptive in this situation (for example, the conspiracy theories), but also used some beneficial strategies that promote health-related behaviors.

\section{Limitations}

Although our results are rich and the study can offer a better understanding of this crisis from a human standpoint, it has some limitations. First, it takes into account only a particular sample of students (those from an Educational Sciences Bachelor Programme), limiting the possibility to extend our findings to other groups of students and, more important, to other age groups. Second, the study only focuses on the answers of women. This was due to the gender disparity existing in the Educational Sciences Bachelor Programme. Again, this impedes our possibility to extend the results. Also, this study offers an insight only on the first days of the crisis. During the following months, many attitudes would probably change, some would disappear while others would become stronger. Thus, we can only discuss the representations, views, and attitudes that were specific to that time period.

\section{Conclusions}

Nonetheless, these shortcomings do not restrain our ability to draw important knowledge from our results. This research is one of the few that applied a real qualitative framework in understanding people's responses during the Covid-19 pandemic. It is also one of the few that took interest in the students' attitudes, a population that was particularly affected. Moreover, it shows how students react during the crisis, what they believe, and how they felt. The study highlights why some strategies used by the state would and did not work, what should be changed and what parts of the students' perceptions and attitudes should be tackled in order to promote adaptive health behaviors during the latter phases of the pandemic. 


\section{Acknowledgement}

This work was co-funded by the European Social Fund, through Operational Programme Human Capital 2014-2020, project number POCU/380/61131123623, project title $<<\mathrm{PhD}$ Students and Postdoctoral Researchers Prepared for the Labour Market! $>>$.

\section{References}

Abrams, D., \& Hogg, M. A. (1990). Social identification, self-categorization and social influence. European Review of Social Psychology, 1, 195-228. https://doi.org/10.1080/14792779108401862

Azlan, A. A., Hamzah, M. R., Sern, T. J., Ayub, S. H., \& Mohamad, E. (2020). Public knowledge, attitudes and practices towards COVID-19: A crosssectional study in Malaysia. Plos one, 15(5), e0233668. https://doi.org/ 10.1371/journal.pone. 0233668

Barbour, R. (2008). Doing focus groups. Sage Publications.

Brooks, S. K., Webster, R. K., Smith, L. E., Woodland, L., Wessely, S., Greenberg, N., \& Rubin, G. J. (2020). The psychological impact of quarantine and how to reduce it: Rapid review of the evidence. The Lancet, 395(10227), 912-920. https://doi.org/10.1016/S0140-6736(20)30460-8

Calisher, C., Carroll, D., Colwell, R., Corley, R. B., Daszak, P., Drosten, C., Enjuanes, L., Farrar, J., Field, H., Golding, J., Gorbalenya, A., Haagmans, B., Hughes, J. M., Karesh, W. B., Keusch, G. T., Lam, S. K., Lubroth, J., Mackenzie, J. S., Madoff, L., Mazet, J., Palese, P., Perlman, S., Poon, L., Roizman, B., Saif, L., Subbarao, K., Turner, M. Statement in support of the scientists, public health professionals, and medical professionals of China combatting COVID-19. The Lancet, 395(10226), 42-43. https://doi.org/ $\underline{10.1016 / \text { S0140-6736(20)30418-9 }}$

Cruwys, T., Stevens, M., \& Greenaway, K. H. (2020). A social identity perspective on COVID-19: Health risk is affected by shared group membership. British Journal of Social Psychology, 59(3), 584- 593. https://doi.org/10.1111/bjso. $\underline{12391}$

Douglas, K. M., Sutton, R. M., Callan, M. J., Dawtry, R. J., \& Harvey, A. J. (2016). Someone is pulling the strings: Hypersensitive agency detection and belief in conspiracy theories. Thinking and Reasoning, 22(1), 57-77. https://doi.org/ $\underline{10.1080 / 13546783.2015 .1051586}$

Franks, B., Bangerter, A., \& Bauer, M. (2013). Conspiracy theories as quasi-religious mentality: an integrated account from cognitive science, social representations theory, and frame theory. Frontiers in psychology, 4, 424. https://doi.org/10.3389/fpsyg.2013.00424 
Students' Views on the Covid-19 pandemic: Attitudes, Representations ... Gabriela Monica ASSANTE, Octav Sorin CANDEL

Gilder, E. (2020). Towards a post-pandemic postmodern society - Is the pandemic a deconstruction of the postmodern society? Postmodern Openings, 11(2), 111. https://doi.org/10.18662/po/11.2/153

Harper, C. A., Satchell, L. P., Fido, D., \& Latzman, R. D. (2020). Functional fear predicts public health compliance in the COVID-19 pandemic. International Journal of Mental Health and Addiction. https://doi.org/10.1007/s11469-020$\underline{00281-5}$

Herek, G. M. (2007). Confronting sexual stigma and prejudice: Theory and practice. Journal of Social Issues, 63(4), 905-925. https://doi.org/10.1111/j.15404560.2007.00544.x

Hogg, M. A., Abrams, D., \& Brewer, M. B. (2017). Social identity: The role of self in group processes and intergroup relations. Group Processes \& Intergroup Relations, 20(5), 570-581. https://doi.org/10.1177/1368430217690909

Huberman, A. M., \& Miles, M. B. (1994). Data management and analysis methods. In N. K. Denzin \& Y. S. Lincoln (Eds.), Handbook of qualitative research (p. 428-444). Sage Publications.

Idoiaga, N., Berasategi, N., Eiguren, A., \& Picaza, M. (2020). Exploring children's social and emotional representations of the Covid-19 pandemic. Frontiers in Psychology, 11, 1952. https://doi.org/10.3389/fpsyg.2020.01952

Jaspal, R., \& Nerlich, B. (2020). Social representations, identity threat, and coping amid COVID-19. Psychological Trauma: Theory, Research, Practice, and Policy, 12(S1), S249-S251. http://dx.doi.org/10.1037/tra0000773

Kruger, R. A. (1994). Focus groups: a practical guide to applied research. Sage Publications.

Li, H. (2020). Communication for coproduction: Increasing information credibility to fight the coronavirus. The American Review of Public Administration, 50(6-7), 692-697. https://doi.org/10.1177/0275074020942104

Madriz, E. (2000). Focus groups as feminist research. In N. K. Denzin, \& Y. S. Lincoln (Eds.), Handbook of qualitative research (pp. 835-850). Sage Publications.

Mamzer, H. (2020). Postmodern society and COVID-19 pandemic: Old, new and scary. Society Register, 4(2), 7-18. https://doi.org/10.14746/sr.2020.4.2.01

Mian, A., \& Khan, S. (2020). Coronavirus: the spread of misinformation. BMC medicine, 18(1), 1-2. https://doi.org/10.1186/s12916-020-01556-3

Mikušková, E. B. (2018). Conspiracy beliefs of future teachers. Current Psychology, 37(3), 692-701. https://doi.org/10.1007/s12144-017-9561-4

Mirbabaie, M., Bunker, D., Stieglitz, S., Marx, J., \& Ehnis, C. (2020). Social media in times of crisis: Learning from Hurricane Harvey for the coronavirus disease 2019 pandemic response. Journal of Information Technology, 35(3), 195213. https://doi.org/10.1177/0268396220929258 
Moscovici, S. (1988). Notes towards a description of social representations. European Journal of Social Psychology, 18(3), 211-250. https://doi.org/10.1002 Lejsp.2420180303

Ornell, F., Schuch, J. B., Sordi, A. O., \& Kessler, F. H. P. (2020). "Pandemic fear" and COVID-19: mental health burden and strategies. Brazilian Journal of Psychiatry, 42(3), 232-235. https://doi.org/10.1590/1516-4446-2020-0008

Páez, D., \& Pérez, J. A. (2020). Social representations of COVID-19 (Representaciones sociales del COVID-19). International Journal of Social Psychology, 35(3), 600-610. https://doi.org/10.1080/02134748.2020.1783852

Payne, G., \& Payne, J. (2004). Key concepts in social research. Sage Publications.

Pfattheicher, S., Nockur, L., Böhm, R., Sassenrath, C., \& Petersen, M. (2020). The emotional path to action: Empathy promotes physical distancing and wearing face masks during the COVID-19 pandemic. https://doi.org/10. 31234/osf.io/y2cg5

PlumX Metrics. (2020). Statement in support of the scientists, public health professionals, and medical professionals of China combatting COVID19. The Lancet, 395(10226), e42-e43. https://doi.org/10.1016/S0140-6736 (20)30418-9

Roberto, K. J., Johnson, A. F., \& Rauhaus, B. M. (2020). Stigmatization and prejudice during the COVID-19 pandemic. Administrative Theory and Praxis, 42(3), 364-378. https://doi.org/10.1080/10841806.2020.1782128

Roy, D., Tripathy, S., Kar, S. K., Sharma, N., Verma, S. K., \& Kaushal, V. (2020). Study of knowledge, attitude, anxiety \& perceived mental healthcare need in Indian population during COVID-19 pandemic. Asian Journal of Psychiatry, 51(1), 102083. https://doi.org/10.1016/j.ajp.2020.102083

Savitsky, B., Findling, Y., Ereli, A., \& Hendel, T. (2020). Anxiety and coping strategies among nursing students during the COVID-19 pandemic. Nurse Education in Practice, 46(1), 102809. https://doi.org/10.1016/i.nepr.2020. $\underline{102809}$

Shen, L., Condit, C. M., \& Wright, L. (2009). The psychometric property and validation of a fatalism scale. Psychology and Health, 24(5), 597-613. https://doi.org/10.1080/08870440801902535

Silverman, D. (2000). Doing qualitative research. A practical handbook. Sage Publications. Smith, J. R., \& Hogg, M. A. (2008). Social identity and attitudes. In W. Crano \& R. Prislin (Eds.), Attitudes and attitude change (pp. 337-360). Psychology Press.

Swami, V., Voracek, M., Stieger, S., Tran, U. S., \& Furnham, A. (2014). Analytic thinking reduces belief in conspiracy theories. Cognition, 133(3), 572-585. https://doi.org/10.1016/j.cognition.2014.08.006 
Tajfel, H., \& Turner, J. C. (1979). An integrative theory of intergroup confl ict. In W. G. Austin \& S. Worchel (Eds.), The social psychology of intergroup relations (pp. 33-47). Brooks/Cole.

Wagner, W., Duveen, G., Farr, R., Jovchelovitch, S., Lorenzi-Cioldi, F., Marková, I., \& Rose, D. (1999). Theory and method of social representations. Asian Journal of Social Psychology, 2(1), 95-125. https://doi.org/10.1111/1467$\underline{\text { 839X.00028 }}$

Yang, H., Bin, P., \& He, A. J. (2020). Opinions from the epicenter: An online survey of university students in Wuhan amidst the COVID-19 outbreak1. Journal of Chinese Governance, 5(2), 234-248. https://doi.org/10.1080/ $\underline{23812346.2020 .1745411}$

Zacher, H., \& Rudolph, C. W. (2020). Individual differences and changes in subjective wellbeing during the early stages of the COVID-19 pandemic. American Psychologist. http://dx.doi.org/10.1037/amp0000702

Zipprich, H. M., Teschner, U., Witte, O. W., Schönenberg, A., \& Prell, T. (2020). Knowledge, attitudes, practices, and burden during the COVID-19 pandemic in people with Parkinson's disease in Germany. Journal of Clinical Medicine, 9(6), 1643. https://doi.org/10.3390/jcm9061643 